\title{
Influence of Teaching Experience on Use of Practical Methods among Secondary School Agriculture Teachers in Bureti Sub County, Kenya
}

\author{
Amos Bett, Agnes O. Nkurumwa, James Obara
}

\begin{abstract}
A good teaching method in agriculture provide a basis for a student to gain useful knowledge, learn appropriate skills, and develop a positive attitude towards agriculture as a subject. This is eventually reflected in good performance in the subject by the students. Performance of agriculture subject at Kenya Certificate of Secondary Education (KCSE) level has consistently be low in Bureti Sub-county and the country at large. The purpose of this study was to determine 1he influence of teaching experience on use of practical methods in teaching agriculture in secondary schools in Bureti Sub-county of Kericho County, Kenya. Ex-post facto research design was used. The target population was agriculture teachers of secondary schools in Bureti Sub County. Census sampling was used to select 66 agriculture teachers in 52 secondary schools in the Sub-county. Data was analyzed using Statistical Package for Social Sciences (SPSS), and it involved simple regression analysis and descriptive statistics. The study showed that there is significant influence of teaching experience on use of practical methods in teaching agriculture in secondary schools in Bureti Sub-county. The study recommends that agriculture teachers should be exposed to more hands-on activities during training and be in-serviced more frequently to gain necessary experience so as to be able to conduct practical lessons.
\end{abstract}

Index Terms - Performance, practical methods, secondary schools, teaching experience.

\section{INTRODUCTION}

Teaching experience has a significant effect on pupil performance in primary schools and at upper secondary level 9. Experienced teachers have a richer background of experience to draw from and can contribute insight and ideas to the course of teaching and learning. Such teachers are open to correction and are less dictatorial in classroom. Furthermore, more experienced teachers are considered to be more able to concentrate on the most appropriate way to teach particular topics to students who differ in their abilities, prior knowledge and backgrounds ${ }^{15}$.The experience of the agriculture teacher is developed through the interaction of the teacher with his/her environment. This perspective views agriculture knowledge as emerging from an interaction with the physical and social agriculture environment. Individual teachers have different experiences arising from their training

Amos Bett, Department of Agricultural Education and Extension, Egerton University, P.O. Box 536 - 20115 Egerton -Njoro Agnes Oywaya Nkurumwa, Department of Agricultural Education and Extension, Egerton University, P.O. Box 536 - 20115 Egerton -Njoro James Obara, Department of Agricultural Education and Extension, Egerton University, P.O .Box 536 - 20115 Egerton- Njoro programmes, in-service courses attended and the demands of implementing the curriculum. The teachers' experience will greatly influence their behavior in teaching process. According to ${ }^{5}$ teachers with agricultural experiences have more knowledge and more accurate perceptions of agriculture. Agriculture teachers who have been teaching for longer periods are more exposed to agricultural, activities through doing and seeing, making them more confident and knowledgeable. Studies on the effects of teacher experience on students learning have found a relationship between teacher's effectiveness and their years of experience. According to ${ }^{1}$ teacher play an important role in determining the students' academic achievement.

Agriculture subject emphasizes knowledge, skills and attitude required in all areas of agriculture for proficiency in agricultural production ${ }^{13}$. Hence, one of the principles of agriculture is learning by doing ${ }^{13}$. To be successful, teachers should select and use a wide variety of teaching strategies ${ }^{2}$. The author observed that, the most suitable methods for teaching practical oriented subject like agriculture are demonstration and discussion methods. Other modern approaches require combination of methods to achieve a purpose and include: assignment, project, field-trips and experiments ${ }^{11}$. Studies have found that teachers' experience and educational qualifications significantly influenced students' academic achievement ${ }^{12}$. As observed by ${ }^{8}$, teachers could implement the presentation of theory mixed with actual field practice. Practical classes are always organized to ensure that practical skills are imparted to students to enable them become self-reliant, resourceful and useful to the society ${ }^{13}$. This study was prompted by concern that the subject is not well performed in the County. The performance in the last five years, that is, from the year 2009 to 2014 indicate that the average mean grade for schools in the county was C+ (plus) KNEC reports, (2010, 2012, 2014 and 2015) which is considered as not good performance.

Agriculture is offered as an optional subject in secondary schools where it is expected to be performed well since a learner chooses it because of his or her ability, interest and future benefits of the subject. However, performance has been poor as observed from the KNEC reports. This could be due to challenges faced by teachers that prevent proper implementation of the syllabus. Hence students will not effectively gain the intended knowledge, skills and attitude. This translates to poor performance in the agriculture subject at the KCSE examination, and may discourage students from 
pursuing agriculture-related careers or even practicing agriculture. The challenges faced by the teachers of agriculture may be related to the school, the students, or the teachers themselves. A number of studies have been conducted on school related and student related factors. However, there has not been sufficient study on the influence of teacher related factors on use of practical methods in teaching agriculture, especially teaching experience on use of

practical methods in teaching agriculture in Bureti Sub County of Kericho County. This study sought to fill this gap.

The purpose of this study was to determine the influence of teaching experience on use of practical methods in teaching agriculture in secondary schools in Bureti Sub-county. The following was the specific objective of the study: Determine the influence of teaching experience on use of practical methods in teaching agriculture in secondary schools in Bureti Sub-county. The specific objective was translated into a hypothesis for analytical testing. The study was guided by the following hypothesis: Teaching experience has no statistically significant influence on use of practical methods in teaching agriculture in secondary schools in Bureti Sub County.

This study is guided by Constructivist Theory. The constructivist theorists believe that learning is a process of building meaning ${ }^{10}$. Constructivist teaching strategy is based on the belief that learning is enhanced as learners are actively involved in a process of meaning and knowledge construction rather than passively receiving information. Learners are the makers of meaning and knowledge. Constructivist teaching strategy thus fosters critical thinking and creates motivated and independent learners. Therefore teachers need to employ the right methods of teaching agriculture for effective teaching- learning process.

\section{METHODOLOGY}

The study employed ex-post facto research design. The design was appropriate for this study because it investigates possible relationships among variables without manipulating them. In social science research, an ex-post facto investigation seeks to reveal possible relationships by observing an existing condition or state of affairs and searching back in time for plausible contributing factors ${ }^{7}$.

The study was carried out in Bureti Sub-County of Kericho County, Kenya. The study targeted agriculture teachers from all the public secondary schools in Bureti Sub County. There were 52 secondary schools in the Sub County with a population of 66 agriculture teachers. There were 10 boys' schools with 17 agriculture teachers, 12 girls' schools with 18 teachers and 30 mixed schools (co-educational centre) with 31 agriculture teachers (Teachers Service Commission Office, Bureti Sub-County, 2016). Bureti Sub-county was purposively selected for the study because it had the highest number of schools and also the highest student population in Kericho County. Therefore, it provided a good sample of schools with the required characteristic which the researcher was interested in. A list of all the agriculture teachers was obtained from the sub-county Education Offices. This was a census study and therefore all agriculture teachers from all schools in the Sub County were picked as respondents. This is because different teachers are assigned different forms (i.e. form one to four) in each school. This formed a sample size of 66 agriculture teachers.

A questionnaire was used for gathering data from agriculture teachers. It consisted of closed- ended and open-ended questions. Closed-ended questions were used in quantifying the data obtained while open-ended questions were used in obtaining views and opinions of respondents, which helped in strengthening the data collected. Closed ended questions were chosen because of ease to administer and score while open ended questions were used to seek opinion of the respondents. Data Collection was carried out by the researcher himself. The researcher obtained a list of secondary schools with the number of agriculture teachers in each school. Questionnaires were delivered to the respondents by the researcher personally who assured them of confidentiality of any information given. Both descriptive and inferential statistics were used for data analysis. Descriptive statistics were used to describe the objective and summarize the data collected from the respondents using frequencies and percentages. Hypothesis was analyzed using Simple Linear Regression analysis. The Regression equation which was used is:

$\mathrm{Y}=\alpha+\mathrm{b}_{1} \mathrm{X}_{1}$, where,

$\mathrm{Y}$ is the dependent variable being determined.

$\alpha$ is a constant (Y- intercept) which is coefficient of correlation

$\mathrm{b}_{1}$, is the gradient and shows the correlation coefficient

$\mathrm{X}_{1}$, is independent variable which is used to determine $\mathrm{Y}$, (the dependent variable)

The hypothesis was tested at $95 \%$ confidence level. The Statistical Package for Social Sciences (SPSS) version 22 was used in the data analysis.

\section{RESULTS AND DISCUSSIONS}

To determine the influence of teaching experience on use of practical methods in teaching agriculture in secondary schools in Bureti Sub-county, respondents were asked to indicate their teaching experience as per the following categories; less than 2 years (less experienced), between 2- 4 years (experienced) and 5 years and above(more experienced). The data was analyzed using frequencies and percentage and the results are as shown in the Figure below.

\section{Percentage distibution of agriculture teachers by experience}

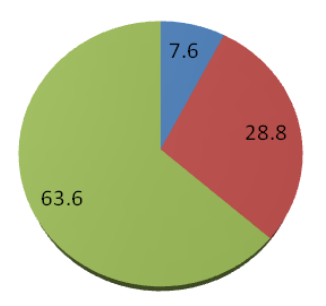

- Less than 2 years

2 to 4 years

5 and above years

experienced teachers. This is the group which has just started working or teaching. A total of $92.4 \%$ of the respondents in the sub county had an experience of two years and above and 
fall in the category of experienced teachers. They are expected to be well conversant with the requirements of the subject and the recommended methods of teaching for effective teaching and learning process.

These results are in line with study carried out by ${ }^{16}$ in which it found out that teachers' years of experience are a measure of quality and it is imperative in the achievement of students' academic, performance. ${ }^{4}$ is of the view that teaching experience (as represented by number of years of teaching) and teaching qualification are positively correlated with student achievement. Hence teaching experience contributes to his/her output in the teaching- learning process. An experienced teacher is expected to use a variety of practical methods which are supposed to help a learner to understand

Preferred Teaching Methods used by Respondents, $n=66$ the concepts better. Therefore experience of the agriculture teacher has a relationship with performance and the methods of teaching used.

Concerning teaching methods, respondents were asked to indicate in the Likert scale the extend they agreed with statements concerning teaching methods they use in teaching agriculture subject. The Likert scale was coded as; Strongly Disagree $=1$, Disagree $=2$, Neutral or Undecided $=3$, Agree $=$ 4 and Strongly Agree $=5$. The teaching methods selected were; Use of lecture method, assignments and group work, Project work, Field visits, Demonstrations and use of practical methods in teaching agriculture subject. These are some of the methods commonly used in teaching agriculture. The results are as shown in the Table.

\begin{tabular}{|l|l|l|l|}
\hline $\begin{array}{l}\text { Statement Related to preferred teaching } \\
\text { method }\end{array}$ & Disagree & Neutral & Agree \\
\hline $\begin{array}{c}\text { Lecture method is effective method of } \\
\text { teaching }\end{array}$ & 77.2 & $\%$ & 0.0 \\
\hline $\begin{array}{l}\text { Assignment is effective method of teaching } \\
\text { agriculture }\end{array}$ & 60.1 & 22.7 & 1.5 \\
\hline $\begin{array}{l}\text { Practical is effective method of teaching } \\
\text { agriculture }\end{array}$ & 0.0 & 37.9 & 62.1 \\
\hline $\begin{array}{l}\text { Demonstration is effective method of } \\
\text { teaching }\end{array}$ & 0.0 & 25.8 & 74.2 \\
\hline $\begin{array}{l}\text { Group work is effective method of teaching } \\
\text { agriculture }\end{array}$ & 1.5 & 94 & 4.5 \\
\hline $\begin{array}{l}\text { Project work is effective method of teaching } \\
\text { agric. }\end{array}$ & 15.2 & 4.5 & 63.6 \\
\hline $\begin{array}{c}\text { Field visits is effective method of teaching } \\
\text { agriculture }\end{array}$ & 0.0 & 100 & 0.0 \\
\hline
\end{tabular}

From these results, the respondents prefer demonstration method (74.2\%), practical methods (62.1\%) and project work method $(63.6 \%)$ of teaching agriculture. These results are in tandem with findings of studies carried out by Daluba (2013) which recommends a more interactive teaching method such as demonstration method as it has a significant effect on students' achievement compared to the conventional lecture method. The respondents were neutral or undecided about field visits. This could be because field visits are more involving in terms of finances and requires more time to go out of school which may not be feasible logistically. Suitable areas to visit may also not be available within the locality of the school. Demonstration and practical methods are the preferred methods of teaching agriculture.

Cross tabulation of experience and teaching methods was done to see the influence of experience on the preferred methods of teaching. The results are as shown in the Table.

\section{Cross - Tabulation of Experience and Teaching Methods, $n=66$}

Statement Related \% of Less than 2 years \% of 2 to 4 years of experience to preferred method of of experience teaching
$\mathrm{N}$
A

$\mathrm{D}$

A
D

$\mathrm{N}$

$\mathrm{N}$

A
D $\%$ of 5 and above years of experience

Lecture method is effective method of teaching agric.

Assignment is

effective method of teaching agric.
1.5
18.2
10.6
0
57.5
6.1
0 
Practical is effective method of teaching agric.

$\begin{array}{lllllllll}0 & 0 & 7.6 & 6.1 & 0 & 22.7 & 0 & 1.5 & 62.1\end{array}$

Demonstration is effective method of teaching

Group work is effective method of teaching

$\begin{array}{lllllllll}0 & 1.5 & 6.1 & 0 & 6.1 & 30.7 & 0 & 2.2 & 53.4\end{array}$

$\begin{array}{llllllll}0 & 6.1 & 1.5 & 9.1 & 1.5 & 18.2 & 21.2 & 0\end{array}$

Project work is effective method of teaching

Field visits is effective method of teaching agric.

From the results a total of $90.2 \%$ of all the respondents across all the years of teaching experience preferred demonstration method. $92.4 \%$ of all the respondents across all the years of teaching experience preferred use of practical method in teaching agriculture. $77.2 \%$ of all the respondents across all the years of teaching experience did not prefer use of lecture method. All the respondents (100\%) across all the years of teaching experience were neutral or undecided about field visits as a teaching method. The respondents did not prefer lecture method and this is also in line with the findings of ${ }^{3}$. Lecture method is criticized as ineffective as it turns the learners into passive participants in the teaching and learning process, though it is useful in covering large content of work within a short time. The lecture method causes the teacher to dominate the teaching-learning process with very little participation on the part of the learners. A more interactive teaching method such as the demonstration method is recommended as it has been found to have a significant effect on students' achievement compared to the conventional lecture method. Field visits method ranked the list popular

\section{Model Summary b} respondents might not have been aware of the places to visit, lack of time and may be the cost involved since students have to be taken out.

Simple Linear Regression (SLR) was used to test the hypothesis. SLR is a technique used to estimate the influence of independent variable $(x)$ on the dependent $(y)$. This is defined by a linear equation which is a regression formula given by; $\mathrm{Y}=\mathrm{b}_{0}+\mathrm{b}_{1} \mathrm{x}_{1}$. Where $\mathrm{y}$ (predicted score on dependent variable $)=b_{0}$ (Constant $)+b_{1}$ (Slope) $x$. The independent variable is teaching experience.

The hypothesis thus stated: Teaching experience has no statistically significant influence on use of practical methods in teaching agriculture in secondary schools in Bureti Sub County.

Simple regression analysis was carried out to determine the degree to which predictor variables $\left(\mathrm{x}_{1}\right)$ which is teaching experience accounts for the criterion variable $(y)$ which is use of practical method in teaching agriculture. The results are shown in model summary in the Table.

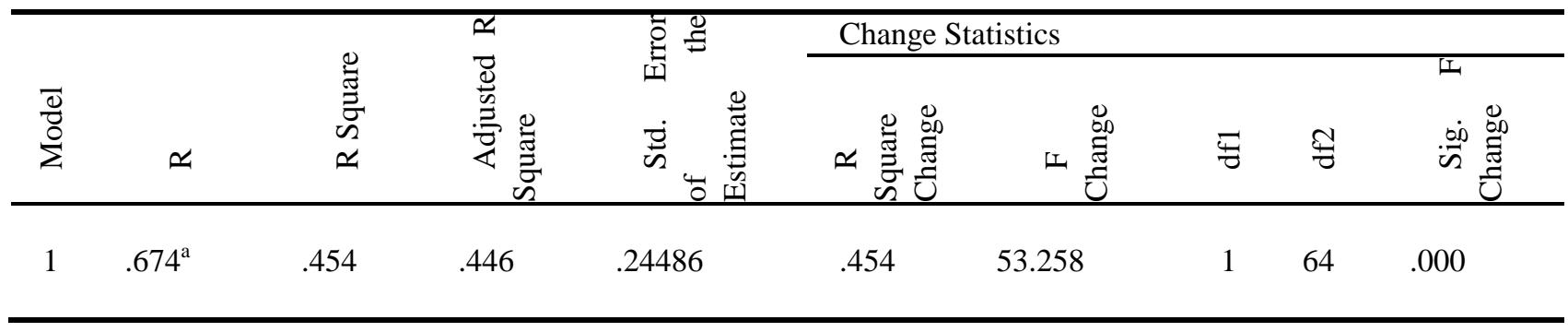

a. Predictors: (Constant), $\mathrm{X}_{1}$ : Experience

b. Dependent Variable: $y 1$ 
In this model summary output, $\mathrm{R}^{2}$ describes the degree to which the predictor variable $\left(\mathrm{x}_{1}\right)$ which is teaching experience accounts for the criterion variable (y) which is use of practical methods. In this case $\mathrm{R}^{2}=0.454$, which is significant at $F=$ 0.00 and implies that the predictor variable explain $45.5 \%$ of the variation in the criterion or dependent variable. Thus teaching experience accounts for $45.5 \%$ on use of practical method in teaching agriculture. This means that the more a teacher is experienced, the more such a teacher will employ practical method of teaching agriculture than a less experienced one.

In the $\mathrm{ANOVA}^{\mathrm{a}}$ results, $F=53.258$ and $p=0.000$. Hence the regression equation is highly significant.

Anova

\begin{tabular}{lllllll}
\hline \multicolumn{2}{l}{ Model } & Sum of Squares & Df & Mean Square & F & Sig. \\
\hline \multirow{2}{*}{1} & Regression & 3.193 & 1 & 3.193 & 53.258 & $.000^{\mathrm{b}}$ \\
& Residual & 3.837 & 64 & .060 & & \\
& Total & 7.030 & 65 & & & \\
\hline
\end{tabular}

a. Dependent Variable: y1

b. Predictors: (Constant), $\mathrm{X}_{1}$ : Experience

The regression coefficients constant, $\left(b_{0}\right)$ in the regression formula is 1.264 . The un-standardized or raw score regression coefficient $\left(\mathrm{b}_{1}\right)$ is 0.216 . The $t$ value is significant at $p=0.000$ and that teaching experience is a significant predictor on use of practical methods in teaching agriculture. It has a positive influence and regression equation can be formulated as $\mathrm{y}=$ $1.264+0.216 \times 1$. This follows that for every one unit increase in $\mathrm{x} 1$ (experience), there is 0.216 increase in use of practical methods in teaching agriculture. Therefore the more the number of years one has in the teaching career, the more such a teacher is likely to use practical methods of teaching agriculture. The null hypothesis that teaching experience has no statistically significant influence on use of practical methods in teaching agriculture in secondary schools in Bureti Sub County is rejected. Therefore alternative hypothesis that teaching experience has statistically significant influence on use of practical methods in teaching agriculture in secondary schools in Bureti Sub County is accepted.

\section{CONCLUSIONS AND RECOMMENDATIONS}

Teaching experience influence use of practical methods in teaching agriculture. More experienced teachers are likely to use more practical methods of teaching agriculture. Teachers should be exposed to more practical methods of teaching agriculture during their training in teacher training colleges and in the university.

Agriculture teachers should be in-serviced more frequently so as to keep them on track with appropriate methods of teaching agriculture using practical methods as technology keeps on changing. Practical activities have positive impact on learners as it improves the ability to retain the content.

\section{REFERENCES}

[1] Adeyemi B. (2010). Teacher Related Factors as Correlates of Pupils Achievement in Social Studies in South West Nigeria. Electronic Journal of Research in Education Psychology 8(1):313-332.

[2] Auwal, A. (2013). Effects of teaching method on retention of Agricultural Science knowledge in senior secondary schools of Bauchi Local Government Area, Nigeria.Vi.4 (4), International Journal of Science and Technology Educational Research.

[3] Daluba, N. E 2013. Effect of Demonstration Method of teaching on Students' Achievement in Agricultural Science. World Journal of Education 3(6), 1-7.
[4] Darko, R.O., Yuan, S., kwesi, S., Abbey, A., Liu, J. and Kumi, F. (2016). Constraints Encountered I Teaching Practical Agriculture In Selected Senior High Schools In The Sekondi- Takoradi Metropolis International Journal of Information Research and Review Vol. 03, Issue, 07,Pp.2604-2611, July, 2016.

[5] Humphrey, J. K., Stewart, B. R. \& Linhard, R. E. (1994). Pre-service elementary education majors' knowledge of and perceptions towards agriculture. Journal of Agriculture Education, 35(2), 27-30.

[6] Kenya National Examinations Council (KNEC). (2010). Examination Regulations and Syllabuses for the Kenya Certificate of Secondary Education (KCSE) Examination 2010-2011. KNEC, City Square, Nairobi: Kenya.

[7] Kerlinger, F. N. \& Rint (1986). Foundations of behavioral Research $\left(3^{r d} . E d\right.$.) Fort Worth, TX: Holt, Rinehart, and Winston.

[8] Kidane, T. T. \& Worth, S. H. (2015). The Attitude of High School Agricultural Science Teachers towards Agricultural Education Training in South Africa. Journal of Human Ecology, 50(2):129-142 (2015)

[9] Kosgei, A., Mise, J. K., Odera, O. \& Ayug, M. E., (2013).Influence of teacher characteristics on students' academic achievement among secondary schools. Journal of Education and Practice, Vol.4, No.3, 2013.

[10] Merriam, S. B. \& Cafferella, R. S. (1999). Learning in adulthood: AS comprehensive guide ( $2^{\text {nd }}$ Edition). San Francisco, C. A: Jossey- Base Publishers.

[11] Modebelu, M. N. \& Nwakpadolu, G. M. (2013). Effective Teaching and Learning of Agricultural Science for Food Security and National Sustainability. Journal of Educational and Social Research. Vol. 3 (4) July 2013.

[12] Njeru, E. H. N. Orodho, J. A. (2003). Access and Participation in Kenya. Nairobi. Institute Policy Analysis and Research. Raleigh.

[13] Olajide, K., Odoma, M. O., Okechukwu, F., Iyare, R. \& Okhaimoh, K. I. (2015). Problems of teaching agricultural practical in secondary schools in delta state, Nigeria, International Journal of Innovative Education Research 3 (2):7-12, April-June 2015.

[14] Olaleye, F. O. (2011). Teachers Characteristics as Predictor of Academic Performance of Students in Secondary Schools in Osun State-Nigeria. European Journal of Educational Studies 3(3),p p 505-511.

[15] [15]. Stringfield, S. \& Teddlie, C. (1991). School, Classroom and students' Level Indicators of Rural School Effectiveness A Journal of Research in Rural Education, 7(1):15-28.

[16] [16]. Yusuf, H. O. and Dada, A.A. (2016). Impact of teachers' qualification and experience on the Performance of students in colleges of education in Kaduna state, Nigeria, The Online Journal of Quality in Higher Education - April 2016 Volume 3, Issue 2. 